\title{
Hint2, the mitochondrial nucleoside 5'-phosphoramidate hydrolase; properties of the homogeneous protein from sheep (Ovis aries) liver
}

\author{
Ewa Bretes', Anna M. Wojdyła-Mamoń1, Joanna Kowalska², Jacek Jemielity2,3, \\ Renata Kaczmarek4, Janina Baraniak ${ }^{4}$ and Andrzej Guranowski ${ }^{\bowtie}$
}

1Department of Biochemistry and Biotechnology, Poznań University of Life Sciences, Poznań, Poland: 2Division of Biophysics, Institute of Experimental Physics, Faculty of Physics, University of Warsaw, Warsaw, Poland; ${ }^{3}$ Centre of New Technologies, University of Warsaw, Warsaw, Poland;

${ }^{4}$ Department of Bioorganic Chemistry, Center of Molecular and Macromolecular Studies, Polish Academy of Sciences, Łódź, Poland

\begin{abstract}
Adenosine 5'-phosphoramidate $\left(\mathrm{NH}_{2}-\mathrm{pA}\right)$ is a rare natural nucleotide and its biochemistry and biological functions are poorly recognized. All organisms have proteins that may be involved in the catabolism of $\mathrm{NH}_{2}-\mathrm{pA}$. They are members of the HIT protein family and catalyze hydrolytic splitting of $\mathrm{NH}_{2}-\mathrm{pA}$ to $5^{\prime}$-AMP and ammonia. At least five HIT proteins have been identified in mammals; however, the enzymatic and molecular properties of only Fhit and Hint 1 have been comprehensively studied. Our study focuses on the Hint 2 protein purified by a simple procedure to homogeneity from sheep liver mitochondrial fraction (OaHint2). Hint1 protein was also prepared from sheep liver (OaHint1) and the molecular and kinetic properties of the two proteins compared. Both function as homodimers and behave as nucleoside 5'-phosphoramidate hydrolases. The molecular mass of the OaHint2 monomer is $16 \mathrm{kDa}$ and that of the OaHint 1 monomer $14.9 \mathrm{kDa}$. Among potential substrates studied, $\mathrm{NH}_{2}-\mathrm{pA}$ appeared to be the best; the $K_{\mathrm{m}}$ and $k_{\text {cat }}$ values estimated for this compound are $6.6 \mu \mathrm{M}$ and $68.3 \mathrm{~s}^{-1}$, and $1.5 \mu \mathrm{M}$ and $11.0 \mathrm{~s}^{-1}$ per natively functioning dimer of OaHint2 and OaHint1, respectively. Studies of the rates of hydrolysis of different $\mathrm{NH}_{2}-\mathrm{pA}$ derivatives show that Hint2 is more specific towards compounds with a $\mathrm{P}-\mathrm{N}$ bond than Hint1. The thermostability of these two proteins is also compared.
\end{abstract}

Key words: histidine triad nucleotide binding proteins, nucleoside $5^{\prime}$-phosphoramidase, Hint1, Hint2, purification to homogeneity

Received: 28 March, 2013; revised: 04 June, 2013; accepted: 10 June, 2013; available on-line: 14 June, 2013

\section{INTRODUCTION}

Adenosine 5'-phosphoramidate $\left(\mathrm{NH}_{2}-\mathrm{pA}\right)$ is believed to occur in all organisms. However, only one paper by Frankhauser and coworkers (1981a) has reported the detection of this compound among cellular nucleotides purified from the green alga Chlorella pyranoidosa. The same authors showed that $\mathrm{NH}_{2}-\mathrm{pA}$ is a product of the following reaction catalyzed by adenylylsulfate:ammonia adenylyltransferase (EC 2.7.7.51):

$\mathrm{SO}_{4}^{-} \mathrm{pA}+\mathrm{NH}_{4}^{+} \rightarrow \mathrm{NH}_{2}-\mathrm{pA}+\mathrm{SO}_{4}^{2-}+2 \mathrm{H}^{+}$.

They demonstrated this transferase activity in Ch. $p y$ ranoidosa, Euglena gracilis, Dictyostelium discoideum, Escherichia coli, and in higher plants such as spinach and barley (Frankhauser et al., 1981b). Recently, we have found the same activity in mammalian tissues (Wojdyła-Mamoń \& Guranowski, unpublished). The supposition that $\mathrm{NH}_{2}-\mathrm{pA}$ is a ubiquitous compound and that its concentration is enzymatically controlled may be supported by the existence of various proteins that catalyze the cleavage of $\mathrm{NH}_{2}$-pA to ammonia and either 5'-AMP (by hydrolysis) (Rossomando \& Hadjimichael, 1986; Kuba et al., 1994; Bieganowski et al., 2002; Guranowski et al., 2008; 2010a; 2010b; 2011) or 5'-ADP (by phosphorolysis) (Guranowski et al., 2010a). All these enzymes probably belong to the histidine triad (HIT) superfamily and have a HIT motif in their active sites. HIT genes occur in various phyla, where the HIT proteins can control the metabolism of mononucleotides such as the aforementioned $\mathrm{NH}_{2}-\mathrm{pA}$ and $\mathrm{SO}_{4}-\mathrm{pA}$ (Guranowski et al., 2008; $2010 \mathrm{a} ; 2010 \mathrm{~b})$ and of dinucleoside polyphosphates, e.g., ApppA (Barnes et al.,1996) and mRNA caps (Cohen et al., 2004; Banerjee et al., 2009).

Our knowledge about the biological functions of nucleoside phosphoramidates and different HIT proteins is stile obscure. One of these proteins, Hint1, have been shown to mediate the activities of protein kinases (Bieganowski et al., 2002) and to interact with certain transcription factors (Korsisaari \& Mäkelä, 2000; Carmi-Levy et al., 2008; Weiske \& Huber, 2005). Hint2, which is expressed in mitochondria, has also been demonstrated to act as a nucleoside phosphoramidase and, in addition, to sensitize hepatocarcinoma cells to apoptosis (Martin et al., 2006) and to affect steroidogenesis in H295R cells, a classical model commonly used for investigating adrenal steroid biosynthesis (Lenglet et al., 2008). The Hint and other HIT proteins (Fhit, aprataxin) have attracted particular interest due to the considerable evidence for their actions as tumor suppressors; see Martin et al. (2011) for review. Yet the detailed molecular mechanisms by which these proteins regulate carcinogenesis await elucidation. So far, there is no evidence that enzymatic activities of Hint proteins are essential for their biological role (Korisaari et al. 2003; Weiske \& Huber, 2006). However, the HIT protein superfamily is very old and evolution-

e-mail: guranow@up.poznan.pl

Abbreviations: Aptx, aprataxin; Fhit, fragile histidine triad protein; HIT, histidine triad; Hint, histidine triad nucleotide binding protein; MALDI-TOF, matrix assisted laser desorption/ionization-time of flight; ApppA, diadenosine 5', 5"'- $P$ 1, $P^{3}$-triphosphate; $\mathrm{NH}_{2}-\mathrm{pA}$, adenosine 5'-phosphoramidate; $\mathrm{NH}_{2}-\mathrm{pC}$, cytidine 5'-phosphoramidate; $\mathrm{SO}_{4}-\mathrm{pA}$, adenosine 5'-phosphorosulfate; $\mathrm{SO}_{4}-\mathrm{pC}$, cytidine 5'-phosphorosulfate; S-pA, adenosine 5'-phosphorothioate; S-pG, guanosine 5'-phosphorothioate; F-pA, adenosine 5'-phosphorofluoride. 
arily conserved. The amino acid conservation concerns mainly the active center and this might point to the biological significance of the considered enzymatic activity. One can also speculate that a very early function of the HIT proteins was to remove nucleoside phosphoramidates and dinucleoside polyphosphates - compounds that could form under prebiotic conditions (Lohrmann, 1997). Since these compounds can be also side-products of certain enzymatic reactions, the aforementioned putative function of HIT proteins may still be valid. Conditions that favor formation of these uncommon nucleotides in the cells of contemporary organisms have been studied and reviewed (McLennan, 2000).

Recently, we studied the substrate specificity of nine recombinant HIT-proteins with seven nucleotides their potential substrates (Guranowski et al., 2010b). The general conclusion of the study was that the individual proteins differ in their preferential recognition of these compounds as substrates. However, they appeared to fall into two distinct groups. One comprises the human, plant (Arabidopsis thaliana) and protozoan (Trypanosoma brucel) Fhit proteins, which exhibit quite a broad substrate specificity and catalyze efficient degradation of both dinucleoside polyphosphates (ApppA, $\mathrm{m}^{7} \mathrm{Gppmm}^{7} \mathrm{G}$ ) and mononucleotides ( $\mathrm{SO}_{4}-\mathrm{pA}, \mathrm{NH}_{2}-\mathrm{pA}$ and $\left.\mathrm{F}-\mathrm{pA}\right)$. The second group consists of AtHint1, AtHint3, AtHint4, AtAptx (A. thaliana aprataxin-like protein) and EcHinT proteins, which did not catalyze hydrolysis of dinucleoside polyphosphates but efficiently degraded $\mathrm{NH}_{2}-\mathrm{pA}$. At the time we performed those studies (Guranowski et al., 2010a; 2010b), none of the Hint2 proteins was available. Based on the information that Hint2 is predominantly expressed in liver and pancreas and is localized to mitochondria (Martin et al., 2006; Lenglet et al., 2008), we have developed a purification procedure which yields homogeneous Hint2 from sheep liver mitochondria. A kinetic and molecular characterization of this protein is presented below, which supplements existing data on the substrate specificity of the HIT-proteins.

\section{MATERIALS AND METHODS}

Chemicals. Common nucleotides, adenosine 5'-phosphoramidate $\left(\mathrm{NH}_{2}-\mathrm{pA}\right)$, adenosine 5'-phosphorothioate (S-pA) and most of the general reagents were purchased from Sigma, St. Louis, MO, USA. Adenosine 5'-phosphorosulfate $\left(\mathrm{SO}_{4}-\mathrm{pA}\right)$ and cytidine 5'-phosphorosulfate ( $\left.\mathrm{SO}_{4}-\mathrm{pC}\right)$ (Kowalska et al., 2012), guanosine 5'-phosphorothioate (S-pG) (Mukaiyama \& Hashimoto, 1971), and adenosine 5'-phosphorofluoride (F-pA) (Wittman, 1963) were prepared as described previously. Cytidine 5'-phosphoramidate $\left(\mathrm{NH}_{2}-\mathrm{pC}\right)$ was prepared as described by Chambers and Moffatt (1958). Briefly, cytidine 5'-phosphate $(0.1 \mathrm{mmol})$ was dissolved in a mixture of $2 \mathrm{M}$ ammonium hydroxide $(250 \mu \mathrm{L})$ and dimethylformamide $(170 \mu \mathrm{L})$ and into this solution dicyclohexylcarbodiimide (100 mg, $0.5 \mathrm{mmol})$ dissolved in t-butyl alcohol $(650 \mu \mathrm{L})$ was added. The two-phase reaction mixture was heated at $80^{\circ} \mathrm{C}$ for 8 hours and then allowed to stand overnight at room temperature. The precipitated dicyclohexylurea was removed by filtration and washed 3 times with water. The t-butyl alcohol was removed under reduced pressure and the aqueous dimethylformamide solution extracted 3 times with ether. Then water was removed under reduced pressure and the desired product was isolated using ion-exchange chromatography (DEAE-Sephadex A-25) with triethylammonium bicarbonate buffer (from 0.0 to $0.4 \mathrm{M}, \mathrm{pH} 7.5$ ) as the eluent. $\mathrm{NH}_{2}$ - $\mathrm{pC}$ was
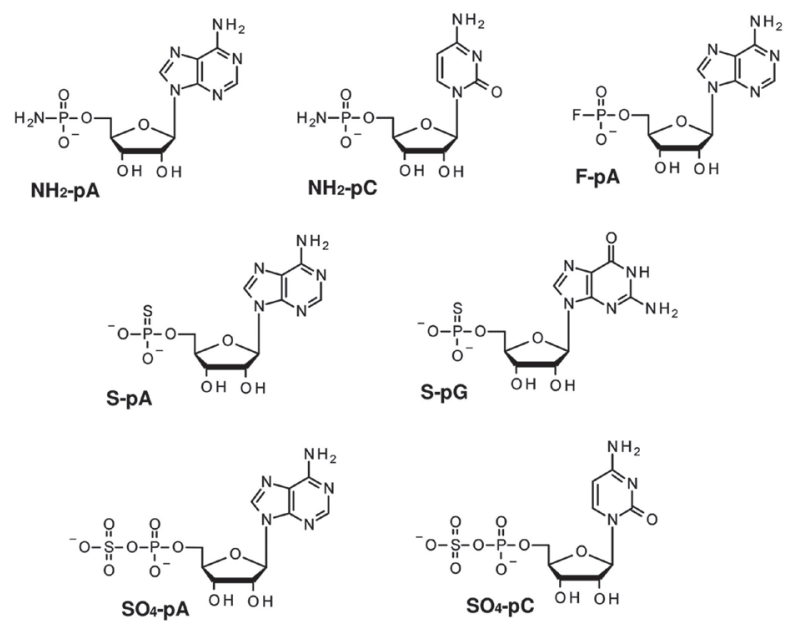

Figure 1. Structures and abbreviations of compounds used in this study.

obtained with 93\% yield and its identity confirmed by ${ }^{31} \mathrm{P}-\mathrm{NMR}\left(\mathrm{D}_{2} \mathrm{O}\right)$ and fast atom bombardment mass spectrometry analyses. Structures of the nucleotides used as substrates are shown in Fig. 1.

Radiolabeled $\left[8{ }^{3} \mathrm{H}\right]$ adenosine-5'-phosphoramidate was purchased from Moravek Biochemicals, Brea, CA, USA.

Chromatographic systems. Analyses of the hydrolysis of $\mathrm{NH}_{2}-\mathrm{pA}$ and its analogs were performed on TLC aluminum plates precoated with silica gel containing fluorescent indicator (Merck KGaA, Darmstadt, Germany, cat. no. 5554) which were developed in dioxane: $25 \%$ ammonia:water (6:1:4, v/v/v). Ion-exchange chromatography and gel filtration were performed on DEAESephacel, Sephadex G-75 superfine, and Sephadex G-100 columns (Pharmacia Fine Chemicals AB, Uppsala, Sweden). Affinity elution of the sheep Hint proteins was performed from 6-AH-AMP-agarose (Jena Bioscience, Jena, Germany, cat. no. AC-145L) in which the AMP ligand is attached to the agarose support via an aminohexyl spacer at its $\mathrm{N}^{6}$ atom.

Buffers. Buffer A: $10 \mathrm{mM}$ Tris/ $\mathrm{HCl}(\mathrm{pH} 8.8)$ containing 5\% glycerol and $1 \mathrm{mM} 2$-mercaptoethanol. Buffer B: $50 \mathrm{mM}$ potassium phosphate $(\mathrm{pH}$ 6.8) containing 5\% glycerol and $1 \mathrm{mM}$ 2-mercaptoethanol. Buffer C: 10 $\mathrm{mM}$ Tris $/ \mathrm{HCl}$ ( $\mathrm{pH}$ 7.4) containing $0.25 \mathrm{M}$ sucrose, 0.1 mM EGTA and $0.2 \%$ bovine serum albumin.

Analytical methods. Protein concentration was estimated by the turbidimetric tannin method (MejbaumKatzenelenbogen, 1955). MALDI-TOF mass spectrometric analysis was performed at the proteomics facility of the Institute of Biochemistry and Biophysics, Polish Academy of Sciences, Warsaw, Poland. Peptides that corresponded to the protein of the highest score were analyzed in the MASCOT Search Program. Molecular masses of the native enzymes were estimated by gel filtration on a Sephadex G-100 column (Andrews, 1964) and of the denatured proteins by SDS/PAGE.

Enzyme assay. Qualitatively, during purification of the proteins nucleoside phosphoramidate hydrolase activity was measured in a reaction mixture $(50 \mu \mathrm{L})$ containing $50 \mathrm{mM}$ potassium phosphate $(\mathrm{pH} 6.8), 1 \mathrm{mM}$ substrate, bovine serum albumin $(0.2 \mathrm{mg} / \mathrm{mL})$, other additions (if any), and a rate-limiting amount of either OaHint1 or OaHint2. When the $K_{\mathrm{m}}$ values were being estimated, the $\mathrm{NH}_{2}-\mathrm{p}\left[8-\mathrm{H}^{3}\right] \mathrm{A}$ concentration varied between 1.9 and $31.2 \mu \mathrm{M}$ and the mixture contained either 45 pg OaHint1 or 26 pg OaHint2. At time intervals, 


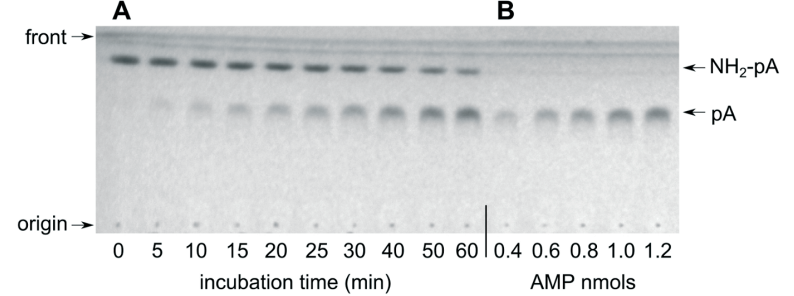

Figure 2. Time-course of hydrolysis of $\mathrm{NH}_{2}-\mathrm{pA}$ catalyzed by sheep liver Hint 1.

It was analyzed by thin-layer chromatography $(\mathbf{A})$ and quantified with AMP standard (B). Part A: The reaction mixture $(50 \mu \mathrm{L})$ contained $50 \mathrm{mM}$ potassium phosphate buffer $(\mathrm{pH} 6.8), 1 \mathrm{mM}$ $\mathrm{NH}_{2}-\mathrm{pA}$ and $0.22 \mu \mathrm{g}$ OaHint1. The reaction was carried out at $37^{\circ} \mathrm{C}$. At time intervals $2-\mu \mathrm{L}$ aliquots were spotted onto the TLC plate origin. Part B: Indicated amounts of $5^{\prime}$-AMP $(\mathrm{pA})$ were spotted onto the origin. The chromatogram was then developed in dioxane:25\% ammonia:water $(6: 1 ; 4$, by volume) for $30 \mathrm{~min}$. The chromatogram was dried and the spots of substrate and product/ standard were visualized under short-wave UV light and photographed. Densitometric analysis of the AMP standard spots, within the range shown in $B$, revealed perfect linearity of the dependence optical density versus nucleotide amount.
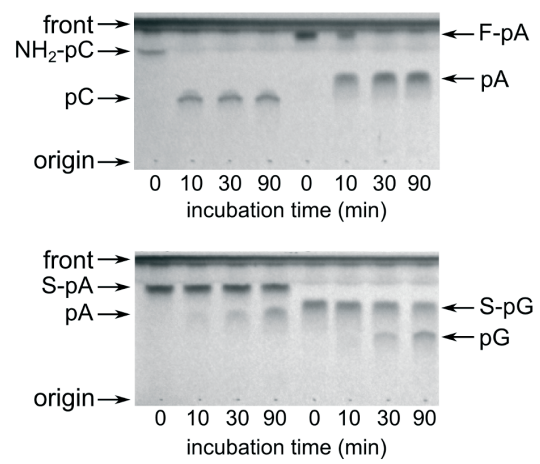

Figure 3. Cleavage of indicated substrates by OaHint2. The reaction mixture $(50 \mu \mathrm{L})$ contained $50 \mathrm{mM}$ potassium phosphate buffer $(\mathrm{pH} 6.8), 1 \mathrm{mM}$ substrate and $0.2 \mu \mathrm{g}$ OaHint2. The incubation and TLC analysis were performed as described in the legend to Fig. 2.

$3-\mu \mathrm{L}$ aliquots of the reaction mixture were spotted onto TLC plates alongside standards of $\mathrm{NH}_{2}-\mathrm{pA}$ and AMP $(\mathrm{pA})$ and the plate developed for $45 \mathrm{~min}$ in the solvent system described above. This system effectively separated nucleoside phosphoramidates from corresponding nucleoside monophosphates, the reaction products (see Figs. 2 and 3 for examples). During kinetic studies, spots of the nucleotides were visualized under short-wave UV light and those of the reaction product ( $\mathrm{pA}$ ) cut out, immersed in scintillation cocktail, and the radioactivity determined. The rates of hydrolysis of unlabeled substrates were analyzed by TLC and densitometry of the reaction product spots by the use of the G:Box Syngene system and the Gene Tools program.

\section{RESULTS}

\section{Hint1 purification}

All operations during purification of OaHint1 and OaHint 2 were carried out at $4^{\circ} \mathrm{C}$. Fresh sheep liver $(100 \mathrm{~g})$ was chopped, suspended in $400 \mathrm{~mL}$ buffer $\mathrm{A}$ and homogenized. The homogenate was centrifuged $(20000 \times g$ for $10 \mathrm{~min})$ and the clear supernatant applied to a DEAE-Sephacel column $(200 \mathrm{ml})$ equilibrated with the same buffer. The column was washed with $1 \mathrm{~L}$ buf- fer $A$ and then a linear $(0-0.5 \mathrm{M} \mathrm{NaCl}$ in the buffer) gradient was applied (total volume $2 \mathrm{~L}$ ). The nucleoside phosphoramidase activity appeared at $80-100 \mathrm{mM}$ $\mathrm{NaCl}$. Active fractions were pooled and the enzyme concentrated by ammonium sulfate precipitation $(70 \%$ saturation). The precipitated proteins were collected by centrifugation $(30000 \times g$ for $15 \mathrm{~min})$, resolubilized in 5 $\mathrm{mL}$ buffer B and applied to a Sephadex G-75 superfine column $(2.5 \times 94 \mathrm{~cm})$ equilibrated with the same buffer. Active fractions, which emerged at $V_{\mathrm{e}} / V_{\mathrm{o}}=1.26$, were pooled and applied to an AMP-agarose column $(1 \mathrm{~mL})$ equilibrated with buffer B. After washing the column with five volumes of buffer $B$, Hint1 was eluted with the same buffer containing $5 \mathrm{mM}$ 5'-AMP. The eluting ligand was removed by dialyzing the fraction against buffer B. Finally, the sample was concentrated by dialysis against dry Sephadex G-200 and stored at $-20^{\circ} \mathrm{C}$ for further analysis. The procedure yielded $225 \mu \mathrm{g}$ of a homogeneous protein identified as OaHint1.

\section{Hint2 purification}

Another protein that exhibited adenosine phosphoramidase activity was purified from the mitochondrial fraction of fresh sheep liver. This fraction was obtained by differential centrifugation as follows: tissue (100 g) was chopped, suspended in $400 \mathrm{~mL}$ buffer $\mathrm{C}$ and gently homogenized in a laboratory knife blender. The debris was removed by centrifugation $(800 \times g$ for $10 \mathrm{~min})$ and the mitochondria collected from the supernatant by centrifugations at $8600 \times g$ for $10 \mathrm{~min}$. The resulting pellet was resuspended in buffer $C$, centrifuged again and the procedure repeated once more. The mitochondrial pellet obtained after the third centrifugation $(14.5 \mathrm{~g})$ was suspended in $50 \mathrm{~mL}$ buffer $\mathrm{A}$ and subjected to sonication. The homogenate was clarified by centrifugation $(20000 \times g$ for $15 \mathrm{~min})$ and the debris suspended again in $10 \mathrm{~mL}$ buffer $\mathrm{A}$, sonicated and the homogenate centrifuged. The two supernatants were combined and applied to a DEAE-Sephacel column. From this stage the purification followed the procedure described above for Hint1, with the mitochondrial nucleoside phosphoramidase emerging from the Sephadex G-75 superfine column at $V_{\mathrm{e}} / V_{\mathrm{o}}=1.14$. This procedure yielded $30 \mu \mathrm{g}$ of a homogeneous protein identified as OaHint2.

\section{Molecular characterization of OaHint1 and OaHint2}

Molecular mass of the native proteins was estimated by gel filtration on a Sephadex G-100 column calibrated with molecular mass standard proteins (Fig. 4). The re-

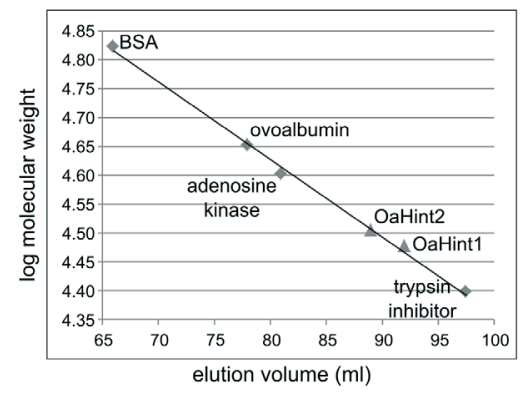

Figure 4. Estimation of molecular masses of native sheep liver OaHint 1 and OaHint2.

Gel filtration was performed on a Sephadex G-100 column (1.6 x $74 \mathrm{~cm})$ equilibrated with $50 \mathrm{mM}$ potassium phosphate buffer $(\mathrm{pH}$ 6.8) containing $5 \%$ glycerol and $1 \mathrm{mM} 2$-mercaptoethanol. The following standards were used: bovine serum albumin (67 kDa), ovalbumin (44 kDa), adenosine kinase from yellow lupin seeds (38 $\mathrm{kDa}$ ) (Guranowski, 1979) and soybean trypsin inhibitor (21.1 kDa). 


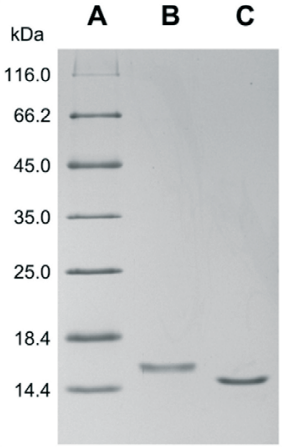

Figure 5. Electrophoresis in the presence of SDS of Hint 1 and Hint2 proteins purified from sheep liver.

Lane A, molecular mass standard proteins (Fermentas, cat. no. SMO 0431); lane B, $0.3 \mu \mathrm{g}$ OaHint2; lane C, $0.6 \mu \mathrm{g}$ OaHint1.

20

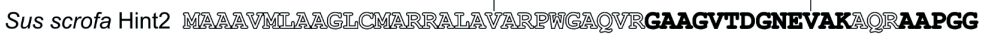
60 AAPTIFSR 120 SQAEEEDQQLLGHLLLVAKKTAKAEGLGDGYRLVINDGKLGAQSVYHLHI 160 HVIGGROLOW:DSG

$$
20
$$

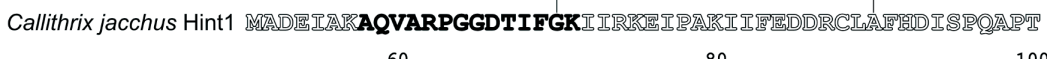

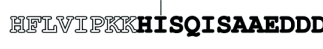

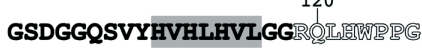

Figure 6. Identification of peptides of the sheep liver Hint proteins by MASCOT Search Program.

The peptides with the best scores for each of these proteins are shown as examples. For OaHint 1 the sequence coverage was $56 \%$ and for OaHint2 $70 \%$. Matched peptides are shown in black bold and the histidine triad motifs in shadowed boxes.

sults of exclusion chromatography under non-denaturating conditions and SDS/polyacrylamide gel electrophoresis (Fig. 5) showed that sheep Hint1 and Hint2 exist as homodimers of about $30 \mathrm{kDa}$ and $32 \mathrm{kDa}$, respectively. Mass spectrometric analysis performed on the homogeneous proteins cut out from the SDS gels revealed their closest similarities to annotated mammalian Hint proteins - OaHint1 to Hint1 proteins of white-tufted-ear marmoset (Callithrix jacchus) and cow (Bos taurus), and OaHint2 to Hint2 proteins of pig (Sus scrofa) and naked

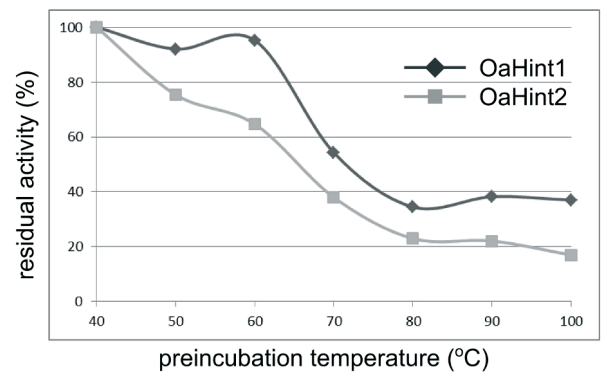

Figure 7. Thermostability of the sheep Hint proteins. The preincubation mixture $(50 \mu \mathrm{L})$ contained $25 \mathrm{mM}$ Tris/ $\mathrm{HCl}(\mathrm{pH}$ 7), $10 \mu \mathrm{M}$ dithiothreitol, $5 \%$ glycerol, bovine serum albumin $(0.1$ $\mathrm{mg} / \mathrm{mL}$ ) and $0.11 \mu \mathrm{g}$ of OaHint 1 or $0.02 \mu \mathrm{g}$ of OaHint2. Preincubation was carried out for $5 \mathrm{~min}$ at the indicated temperature. The mixture was then chilled on ice and a 10- $\mu \mathrm{L}$ aliquot withdrawn and assayed for remaining adenosine phosphoramidase activity, as described in the experimental procedures.

\section{Thermostability}

mole rat (Heterocephalus glaber). Peptide identification of the sheep proteins is presented in Fig. 6 .

\section{Kinetic parameters}

The $\mathrm{pH}$ optima for sheep liver Hint1 and Hint2 were around 7. Thus, hydrolysis of $\mathrm{NH}_{2}-\mathrm{pA}$ and its analogs outinely measured in $50 \mathrm{mM}$ potassium phosphate (pH 6.8). Divalent metal ions were apparently not required for catalysis and the rate of the reaction was not affected by $10 \mathrm{mM}$ EDTA. The hydrolytic cleavage of the P-N bond in $\mathrm{NH}_{2}-\mathrm{pA}$ followed Michaelis-Menten kinetics. The apparent $K_{\mathrm{m}}$ values calculated from EadieHofstee plots $(v$ versus $v /[\mathrm{S}]$ ) were $6.6 \mu \mathrm{M}$ for OaHint2 and $1.5 \mu \mathrm{M}$ for OaHint1. The $k_{\mathrm{cat}}$ values estimated for the natively functioning dimers were $68.3 \mathrm{~s}^{-1}$ and $11.0 \mathrm{~s}^{-1}$, respectively.

\section{Substrate specificity}

Both sheep Hint proteins were tested mainly with the same uncommon (di)nucleotides that had been shown to be substrates for other HIT-proteins (Guranowski et al., 2008; 2010b). Diadenosine triphosphate, ApppA, one of the preferred substrates of Fhit proteins, was hydrolyzed neither by OaHint1 nor by OaHint2, while another good Fhit substrate, adenosine 5'-phosphosulfate $\left(\mathrm{SO}_{4}-\mathrm{pA}\right)$ was a very poor substrate for both sheep proteins. Its rate of hydrolysis catalyzed by OaHint 2 was 5000 -fold and by $\mathrm{Oa}$ Hint1 333-fold lower than that for $\mathrm{NH}_{2}$-pA. As has been shown previously, these features are typical for Hint1 proteins and for their ortholog from Escherichia coli (EcHinT) (Bieganowski et al., 2002; Guranowski et al., 2010b; 2011). The rate of hydrolysis of $\mathrm{SO}_{4}-\mathrm{pC}$, a pyrimidine analog of $\mathrm{SO}_{4}-\mathrm{pA}$, was at the very limit of detection, being one order of magnitude slower than cleavage of $\mathrm{SO}_{4}-\mathrm{pA}$. OaHint1 and Hint2 slowly catalyzed the hydrolysis of the P-S bond in nucleoside 5'-phosphorothioates, S-pA and S-pG (Fig. 3). This property was also previously shown to be typical of Hint1 proteins (Guranowski et al., 2010b; 2011; Ozga et al., 2010). Among those compounds, $\mathrm{NH}_{2}-\mathrm{pA}$ appeared to be hydrolyzed at the highest rate. Its pyrimidine ana$\log \mathrm{NH}_{2}-\mathrm{pC}$ was cleaved at about half this rate. A synthetic adenylyl-derivative, F-pA, also appeared to be a good substrate for the two sheep Hint proteins (Figs. 2 and 3). Results of these studies are summarized in Table 1. Neither OaHint1 nor OaHint2 exhibited the catalytic duality that had been observed earlier for two other HIT-proteins, Arabidopsis thaliana Hint4 and Caenorbabditis elegans DcpS (Guranowski et al. 2010a), i.e., they did not degrade their substrates phosphorolytically.

It is known that nucleoside phosphoramidate hydrolases exhibit remarkable thermostability (Kuba et al., 1994; Guranowski et al., 2010b). Therefore we checked if this was the case with the sheep liver enzymes and whether OaHint1 and OaHint2 differed in this respect from each other. As shown in Fig. 7, the former enzyme was more stable than the latter. OaHint1 retained 
Table 1. Hydrolysis of adenosine 5'-phosphoramidate $\left(\mathrm{NH}_{2}-\mathrm{pA}\right)$ and some other nucleotidyl-derivatives catalyzed by sheep liver OaHint 1 and OaHint2.

The reaction mixtures were prepared as described in the experimental procedures. For poor substrates (bottom four nucleotides), the protein concentration and/or time of incubation was adjusted to get enough products for the densitometric analyses. The $k_{\text {cat }}$ values are means of three independent measurements; standard errors did not exceed $5 \%$

\begin{tabular}{ccccc}
\hline \multirow{2}{*}{ Nucleotide } & \multicolumn{2}{c}{ Activity of OaHint1 } & \multicolumn{2}{c}{ Activity of OaHint2 } \\
\cline { 2 - 5 } & $k_{\text {cat }}\left(\mathrm{s}^{-1}\right)$ & rel. vel. (\%) & $k_{\text {cat }}\left(\mathrm{s}^{-1}\right)$ & rel. vel. (\%) \\
\hline $\mathrm{NH}_{2}$-pA & 11.00 & 100 & 68.30 & 100 \\
\hline $\mathrm{NH}_{2}-\mathrm{pC}$ & 4.98 & 45.30 & 28.65 & 41.90 \\
\hline $\mathrm{F}-\mathrm{pA}$ & 7.90 & 71.80 & 12.6 & 18.40 \\
\hline $\mathrm{S}-\mathrm{pA}$ & 0.18 & 1.60 & 0.43 & 0.60 \\
\hline $\mathrm{S}-\mathrm{pG}$ & 0.29 & 2.60 & 0.70 & 1.00 \\
\hdashline $\mathrm{SO}_{4}-\mathrm{pA}$ & 0.03 & 0.30 & 0.012 & 0.02 \\
\hline $\mathrm{SO}_{4}-\mathrm{pC}$ & 0.004 & 0.04 & $<0.002$ & $<0.002$ \\
\hline
\end{tabular}

full activity after a 5 -min preincubation at $60^{\circ} \mathrm{C}$, whereas OaHint2 lost one third. Moreover, OaHint1 preincubated at 80,90 or $100^{\circ} \mathrm{C}$ retained almost $40 \%$ of its original activity while, under the same conditions, OaHint2 retained only approximately $20 \%$.

\section{DISCUSSION}

Here we describe a procedure that allowed us to obtain (i) native (non-recombinant) Hint2 protein in an electrophoretically homogeneous form for the first time and (ii) homogeneous Hint1 protein from the same biological material (sheep liver). The crucial step of this procedure that separated the sheep liver Hint2 from Hint1 was first to prepare the mitochondrial fraction. Interestingly, the crude cytosolic extract, i.e., the $20000 \times g$ supernatant, from whole sheep liver was apparently free of Hint2. This confirms the mitochondrial localization of Hint 2 and its tight association with mitochondrial membranes, which has been reported recently (Lenglet et al., 2008).

Purification of the two proteins was monitored simply by following their nucleoside phosphoramidase activity by the use of thin-layer chromatography. The final and most effective purification step was affinity chromatography on AMP-agarose, as described earlier by Bieganows$\mathrm{ki}$ and coworkers (2002). Slight modifications of their procedure were: the use of 6-AH-AMP-agarose, an extremely selective resin purchased from Jena Bioscience, and $5 \mathrm{mM}$ AMP, instead of adenosine, as the enzymeeluting agent.

OaHint1 and OaHint2 exhibited many similarities to their native counterparts from rat liver (Kuba et al., 1994) and yellow lupin (Guranowski et al., 2008) and to the recombinant proteins from rabbit (rHint1) (Bieganowski et al., 2002; Ozga et al., 2010), yeast (Hnt1) (Bieganowski et al., 2002) and Arabidopsis thaliana (AtHint1) (Guranowski et al., 2010b). Both the rat liver enzyme (Kuba et al., 1994) and the sheep liver Hints studied here function as homodimers of approximately $30 \mathrm{kDa}$. They hydrolyzed $\mathrm{NH}_{2}$-pA with 2-3 fold higher rates than they did $\mathrm{NH}_{2}-$ pC. OaHint2 seemed to be slightly more specific than OaHint1 with respect to the P-N bond. A comparison of the substrate specificity of these enzymes shows that OaHint 2 is closely related only to Hint1 proteins. This is in line with the very recently published structural similarity and phylogeny of human Hint1 and Hint2 (Maize et al., 2013). Although Hint 2 has features common to all HIT proteins such as the HIT motif, it recognizes only certain nucleotides and would not be able to substitute for Fhits, Hint 3 or Hint4 in the catabolism of natural metabolites such as ApppA or $\mathrm{SO}_{4}-\mathrm{pA}$. Among the other capabilities of OaHint 2 common to Hint1 proteins are the relatively efficient cleavage of the P-F bond in F-pA and the P-S bond in S-pNs. The latter conversion is accompanied by the liberation of $\mathrm{H}_{2} \mathrm{~S}$ (Ozga et al., 2010), easy to smell when one works with these compounds.

The results of this study supplement our knowledge about HIT proteins, in particular their substrate specificity. The new information about native Hint 2 should be taken into account during investigations of the biological function of this mitochondrial protein. In addition to its possible function as a regulatory protein (Lenglet et al., 2008; Martin et al., 2001), it can affect the basic metabolism of certain nucleotides, e.g., $\mathrm{NH}_{2}-\mathrm{pA}$ and $\mathrm{SO}_{4}-\mathrm{pA}$. Hint2 may play the same role in mitochondrial metabolism as does Hint1 in the cytosolic metabolism. From a broader perspective, one can consider nucleoside phosphoramidates and the enzymes degrading them as an example of the "metabolite damage and its repair" concept; see recent review on that issue by Linster and coworkers (2013). Finally, understanding of the metabolism of nucleoside phosphoramidates is important for those who investigate pro-drugs containing $\mathrm{P}-\mathrm{N}$ bonds (Romanowska et al., 2011 and references therein).

\section{Acknowledgements}

This work was supported by the National Science Center (grant 2012/05/B/NZ1/00025).

We thank Dr. Jarosław Zimny (Poznań University of Life Sciences, Poland) for providing sheep liver mitochondria. We are grateful to Professor Alexander G. McLennan (University of Liverpool, UK) for linguistic help in preparation of final version of this paper.

\section{REFERENCES}

Andrews P (1964) Estimation of the molecular weights of proteins by Sephadex gel-filtration. Biochem J 91: 222-233.

Banerjee H, Palenchar JB, Lukaszewicz M, Bojarska E, Stepiński J, Jemielity J, Guranowski A, Ng S, Wah DA, Darżynkiewicz E, Bellofatto V (2009) Identification of the HIT-45 protein from Trypanosoma brucei as an FHIT protein/dinucleoside triphosphatase: Substrate specificity studies on the recombinant and endogenous proteins. RNA 15: 1554-1564.

Barnes LD, Garrison PN, Siprashvili Z, Guranowski A, Robinson AK, Ingram SW, Croce CM, Ohta M, Huebner K (1996) Fhit, a putative tumor suppressor in humans, is a dinucleoside $5^{\prime}, 5^{\prime \prime}-\mathrm{P}^{1}, \mathrm{P}^{3}$-triphosphate hydrolase. Biochemistry 35: 11529-11535.

Bieganowski P, Garrison PN, Hodawadekar SC, Faye G, Barnes LD, Brenner C (2002) Adenosine monophosphoramidase activity of Hint and Hnt1 supports function of kin28, Ccl1, and Tfb3. J Biol Chem 277: 10852-10860.

Carmi-Levy I, Yannay-Cohen N, Kay G, Razin E, Nechushtan H (2008) Diadenosine tetraphosphate hydrolase is part of the transcriptional regulation network in immunologically activated mast cells. Mol Cell Biol 28: 5777-5784.

Chambers RW, Moffatt JG (1958) The synthesis of adenosine-5' and uridine-5'-phosphoramidates. I Am Chem Soc 80: 3752-3755.

Cohen LS, Mikhli C, Friedman C, Jankowska-Anyszka M, Stępiński J, Darżynkiewicz E, Davis RE (2004) Nematode $\mathrm{m}^{7} \mathrm{GpppG}$ and $\mathrm{m}_{3}^{2,2,7} \mathrm{GpppG}$ decapping: activities of Ascaris embryos and characterization of $C$. elegans scavenger DcpS. RNA Biol 5: 1-4.

Frankhauser H, Berkovitz GA, Schiff JA (1981a) A nucleotide with the properties of adenosine 5'-phosphoramidate from Chlorella cells. Biochem Biophys Res Commun 101: 524-532. 
Frankhauser H, Schiff JA, Garber LJ (1981b) Purification and properties of adenylyl sulfate; ammonia adenylyltransferase from Chlorella catalyzing the formation of adenosine 5'-phosphoramidate from adenosine 5'-phosphosulfate and ammonia. Biochem J 195: 545-560.

Guranowski A (1979) Plant adenosine kinase; purification and some properties of the enzyme from Lupinus luteus seeds. Arch Biochem Biophys 196: 220-226.

Guranowski A, Wojdyla AM, Pietrowska-Borek M, Bieganowski P, Khurs EN, Cliff MJ, Blackburn GM, Błaziak D, Stec WJ (2008) Fhit proteins can also recognize substrates other than dinucleoside polyphosphates. FEBS Lett 582: 3152-3158.

Guranowski A, Wojdyla AM, Zimny J, Wypijewska A, Kowalska J, Jemielity J, Davis RE, Bieganowski P (2010a) Dual activity of certain HIT-proteins: $A$. thaliana Hint 4 and $C$. elegans DcpS act on adenosine 5'-phosphosulfate as hydrolases (forming AMP) and as phosphorylases (forming ADP). FEBS Lett 584: 93-98.

Guranowski A, Wojdyla AM, Zimny J, Wypijewska A, Kowalska J, Łukaszewicz M, Jemielity J, Darżynkiewicz E, Jagiełło A, Bieganowski P (2010b) Recognition of different nucleotidyl-derivatives as substrates of reactions catalyzed by various HIT-proteins. New J Chem 34: 888-893.

Guranowski A, Wojdyla AM, Rydzik AM, Stępiński J, Jemielity J (2011) Plant nucleoside 5'-phosphoramidate hydrolase; simple purification from yellow lupin (Lupinus luteus) seeds and properties of homogeneous enzyme. Acta Biochim Pol 58: 131-136.

Korsisaari N, Mäkelä TP (2000) Interactions of Cdk7 and Kin28 with Hint/PKC-1 and Hnt1 histidine triad proteins. J Biol Chem 275: 34837-34840.

Korsisaari N, Rossi DJ, Luukko K, Huebner K, Henkemeyer M, Mäkelä TP (2003) The histidine triad protein Hint 1 is not required for murine development or Cdk7 function. Mol Cell Biol 23: 39293935.

Kowalska J, Osowniak A, Zuberek J, Jemielity J (2012) Synthesis of nucleoside phosphosulfates. Bioorg Med Chem Lett 20: 1699-1710.

Kuba M, Okizaki T, Ohmori H, Kumon A (1994) Nucleoside monophosphoramidate hydrolase from rat liver: purification and characterization. Int J Biochem 26: 235-245.

Lenglet S, Antigny F, Vetterli, L, Dufour J-F, Rossier MF (2008) Hint2 is expressed in the mitochondria of H295R cells and is involved in steroidogenesis. Endocrinology 149: 5461-5469.

Linster CL, Van Schaftingen E, Hanson AD (2013) Metabolite damage and its repair or pre-emption. Natue Chem. Biol. 9: 72-78.
Lohrmann R (1977) Formation of nucleoside 5'-phosphoramidates under potentially prebiological conditions. J Mol Evol 10: 137-154.

Maize KM, Wagner CR, Finzel BC (2013) Structural characterization of human histidine triad nucleotide binding protein 2 (hHint2), a member of the histidine triad (HIT) superfamily. doi: 10.1111/ febs $/ 12330$.

Martin J, St-Pierre MV, Dufour J-F (2011) Hit proteins, mitochondria and cancer. Biochim Biophys Acta 1807: 626-632.

Martin J, Magnino F, Schmidt K, Piguet A-Ch, Lee J-S, Semela D, St-Pierre MV, Ziemiecki A, Cassio D, Brenner Ch, Thorgeirsson SS, Dufour J-F (2006) Hint2, a mitochondrial apoptotic sensitizer down-regulated in hepatocellolar carcinoma. Gastroenterology 130: 2179-2188.

McLennan AG (2000) Dinucleoside polyphosphates - friend or foe? Pharmacol Ther 87: 73-89.

Mejbaum-Katzenelenbogen W (1955) Turbidymetryczna mikrometoda oznaczania białek tanina. Acta Biochim Pol 2: 279-296.

Mukaiyama T, Hashimoto M (1971) Phosphorylation by oxidationreduction condensation. Preparation of active phosphorylating reagents. Bul Chem Soc Japan 44: 2284.

Ozga M, Dolot R, Janicka M, Kaczmarek R, Krakowiak A (2010) Histidine triad nucleotide-binding protein 1 (Hint-1) phosphoramidase transforms nucleoside 5'-O-phosphorothioates to nucleoside 5'-phosphates. J Biol Chem 285: 40809-40818.

Romanowska J, Sobkowski M, Szymańska-Michalak A, Kołodziej K, Dąbrowska A, Lipniacki A, Piasek A, Pietrusiewicz ZM, Figlerowicz M, Guranowski A, Boryski J, Stawiński J, Kraszewski A (2011) Aryl H-phosphonates 17: (N-Aryl)phosphoramidates of pyrimidine nucleoside analogues and their synthesis, selected properties, and anti-HIV activity. J Med Chem 54: 6482-6591.

Rossomando EF, Hadjimichael J (1986) Characterization of cAMP inhibition of a lysyl-(N- $\varepsilon-5$ '-phospho) adenosyl phosphoamidase in Dictyostelium discoideum. Int J Biochem 18: 481-484.

Weiske J, Huber O (2005) The histidine triad protein Hint1 interacts with Pontin and Reptin and inhibits TCF - $\beta$-catenin-mediated transcription. J Cell Sci 118: 3117-3129.

Weiske J, Huber O (2006) The histidine triad protein Hint1 triggers apoptosis independent of its enzymatic activity. J Biol Chem 282: $27356-27366$.

Wittman R (1963) Die Reaktion der Phosphorsäuren mit 2,3-Dinitrofluorobenzol. I: Eine neue Synthese von Monofluorophosphorsäurenmonoestern. Chem Ber 96: 771-779. 